\title{
The Analysis of Pedagogical Content Knowledge of Teacher Candidates
}

\section{Elvi Rahmi}

Dept. of Economics Education, Faculty of Economics, Universitas Negeri Padang, Indonesia

$\square$ (e-mail) elvirahmi.feunp@gmail.com

\begin{abstract}
Students as prospective teachers have unique characteristics, they are required not only to understand the materials, but also to be able to teach the materials to others when they practice to be teachers, or become actual teachers. This study aims to determine and analyze the pedagogical content knowledge of prospective economic teacher. The population on this research was students who attended micro teaching course. The sample was drawn by using purposive sampling approach. Data were collected in observation sheets, consist of materials mastery, the ability in giving apperception and motivation, selection of methods or learning strategies, selection of media and sources, the ability to performance assessment and the ability to involve learner in learning process. The result of research show that in general, the pedagogical content knowledge of teacher candidates is still in the 'sufficient' and 'good' category; thus, it needs a lot of improvement.
\end{abstract}

Keywords: micro teaching, teacher candidates, and pedagogical content knowledge

\section{Introduction}

The learning process is a system and involves several components, where the components interact with each other. Sanjaya $(2006,58)$ describes the components of learning consists of objectives, learning materials, methods or learning strategies, and media and evaluation. The strategy or method is one component that has a very decisive function, however complete and clear other components, if they cannot be implemented through the right strategy then the components will not have meanings in the process of achieving the goal (Sanjaya, 2006, 60). Therefore, every lecturer needs to understand strategies appropriately, be it the right model, method and learning strategies in the implementation of learning process

Arends $(2008,259-260)$ argues that no model of learning is better than the others, he emphasizes that the right model is highly dependent on student characteristics, materials or related learning objectives. Applying the right learning model can be tested by the lecturer as an effort for the students to be interested to follow the learning process. So that the learning outcome from the course can be achieved by the students.

Teacher candidates have unique characteristics, they are required not only to understand the material, but also must to be able to teach the materials to others when they practice to be teachers, or become actual teachers. In shaping the character of highly competent teachers, teacher candidates must be prepared early on so that, teachers can flexibly face many obstacles in the field especially in the digital era today. Digital era requires learning to follow the development of existing learning technology, then that the lecture method should be replaced approaches that use various learning media. Therefore, prospective teachers must be equipped with the ability of classroom management, ability to understand learning strategies and the ability to utilize the media. These abilities will be seen when students attend the micro teaching course

The implementation of micro teaching course aims to provide debriefing or training to prospective teachers with everything needed in the learning process. Starting from the preparation of the lesson plan, implementing the teaching practice and evaluating the lesson. So far, the implementation of micro teaching course has several weaknesses. In the course, students perform their teaching practice 
as it is, by choosing one of the materials in vocational or general high school curriculums (SMA/ SMK) then present the materials in 30-50 minutes. High school economic materials are expected to be mastered range from economic concepts, problems in the economy, roles and economic actors, markets and the establishment of equilibrium prices, the role of banks and financial institutions, payment instruments, management concepts, cooperatives, growth and economic development, employment of national income, national and local government budget ( $A P B N$ and $A P B D$ ), monetary and fiscal policies, the inflation, the Indonesian economic system, the capital market, the cooperative and international trade as well as accounting cycle for service and trading companies.

Whereas, for vocational high school (SMK) materials, economics education students are welcome to choose according to their respective majors. For example, a student from accounting expertise is welcome to choose accounting subject matter, a student from trading major is welcome to choose marketing subject and a student from office administrative major is welcome to choose secretarial subject. It is observed that the students seem less concerned about the relationship between pedagogic competence and professional competence, between their material mastery and their teaching ability. This condition has an impact on the students when conducting the Field Education Practice (PLK), they usually get criticisms and complains from related schools with regards to their teaching competence.

One of solutions for this issue is to improve micro teaching course based on pedagogy content knowledge. The concept of pedagogical content knowledge (PCK) was introduced by Shulman (1986). The concept of PCK refers to teachers' interpretations and transformations of subject-matter knowledge in the context of facilitating student learning. Shulman introduced PCK as a specific category of knowledge (Shulman, 1986, p.9). The key elements in Shulman's conception of PCK are knowledge of representations of subject matter on one hand and the understanding of specific learning difficulties and student conceptions on the other.

A qualified teacher not only transfers knowledge of the subject matter he/she owns, but without a good pedagogy content knowledge, it is difficult for future teachers to understand a new knowledge and construct it with the previous knowledge they have acquired. This is because many teachers do not do the planning in terms of teaching a material and do the best effort to make learning so as to make it something easily comprehensible (Rosnita 2011; Agustina 2015). The relationship between content and pedagogy can be explained as follows. Content knowledge expects teachers to connect and see the relationships between material concepts, while pedagogical knowledge expects teachers to master the ways that can help students learn about the concept (Loughran, 2012). The content knowledge prepares future teachers to learn and teach by inquiry process, while pedagogical knowledge allows teachers to transfer experience to students in the process of inquiry. Based on the above explanation, this study aims to analyze the pedagogical and the content ability of economic teacher candidates.

\section{Methods}

This study is a descriptive study, which attempts to describe and interpret data related to the ability of pedagogy content and ability of prospective teachers. This study is conducted in the field of economics education, where the subjects were the students in micro teaching courses. The sample was drawn by using purposive sampling technique where the researcher chooses certain elements of the population that can be considered informative and representative with the topic of research. Based on the researchers' knowledge of the population, the sample in this study was 16 students representing students in accounting education, trade administration, cooperative and office administration majors.

The data were collected by using structured observation, the observation was on students' pedagogical and content ability when they practice their teaching practice in micro teaching course. An observation guideline was used based on professional teacher appraisal instruments issued by Ministries of Education and Culture of The Directorate General of Teachers and Education Personnel. 
The observation focused on several aspects as follows. First, the material mastery consists of the ability of prospective students to fit the material with planned lesson objectives, the ability to link the material with other relevant knowledge, the accuracy in the material discussion, the systematic presentation of subject matter. Second, the ability in giving apperception and motivation to students which consists the ability to relate material taught with students' experience that, the ability to ask questions that encourage students to learn, the ability to convey the benefits of subject matter so that students interested to learn, ability to convey competence and lesson plans. Third, the strategies selection which consists of the ability to implement learning in accordance with the competence to be achieved, facilitating activities containing exploration, elaboration, and confirmation components, conducting learning in a coherent manner, mastering class, implementing contextual learning, implementing learning that enables the growth of positive habits, implementing learning in accordance with planned allocation of time. Fourth, the utilization of learning resources/media in learning which consists of the use various learning resources, the use of instructional media, selecting appropriate and engaging media messages, engaging learners in the use of learning resources, involveing learners in the use of instructional media. Fifth, the assessment implementation which consists of the ability of prospective teachers in conducting cognitive assessment, affective assessment and skills assessment of learners. Sixth, the Involvement of learners in learning which consists of the ability of prospective teachers in growing active participation of students, through interaction with teachers, other students learning resources, responding positively to students' participation, fostering students' cheerfulness or enthusiasm, and showing a conducive interpersonal relationship.

Table 1 shows a summary of research data based on the observed aspects which refer to the teacher's assessment instruments. The aspects contain professional and pedagogic competencies which consist of:

1) Content knowledge which consists of 4 items that is observed, namely, the ability of the prospective teacher in adapting the material with the purpose of the planned lesson, the ability to link the material with other relevant knowledge, the accuracy in the discussion of the material, the systematic of the presentation of the subject matter,

2) Giving apperception and motivation to the students which consists of 7 observed items, that is, ability to link materials with experience which have owned by student, ability to ask question that encourage student to interested learn, ability to convey the benefit of subject matter so that student interested to learn, ability to convey competence and plan of learning activities,

3) Selection strategy which consists of 9 observed items, that is, the ability to carry out the learning in accordance with the competence to be achieved, facilitate the activities that contain the components of exploration, elaboration, and confirmation, implementing coherent learning, mastering the class, implementing learning contextual, enabling the growth of positive habits, implementing learning in accordance with the planned time allocation,

4) Utilization of learning resources/media in learning which consists of 5 observed items, namely, the ability of prospective teachers in the use of various learning resources, the use of learning media, generate/select messages (media) is appropriate and interesting, involving learners in the utilization of resources learning, involving learners in the utilization of instructional media

5) Implementation of the assessment, which consists of 3 observed items, namely, the ability of prospective teachers in conducting cognitive assessment, affective assessment and skills assessment of learners,

6) Involvement of learners in learning, which consists of 9 observed items, that is, the ability of prospective students in growing students' active participation, through interaction with teachers, other students learning resources, respond positively to participation of students, fostering cheerfulness or enthusiasm of students in learning, indicating a conducive interpersonal relationship. 


\section{Results and Discussion}

Table 1 The pedagogical content knowledge of teacher candidates in Accounting Education major

\begin{tabular}{clccc}
\hline No & \multicolumn{1}{c}{ Aspect } & Mean & Percentage & Remarks \\
\hline 1 & Content Knowledge & 3.81 & 76.25 & Good \\
\hline 2 & Giving aperception and motivation & 4.08 & 81.67 & Good \\
\hline 3 & Strategy & 4.10 & 82.04 & Good \\
\hline 4 & Learning resources/Media & 3.95 & 79.00 & Good \\
\hline 5 & Assessment & 4.00 & 80.00 & Good \\
\hline 6 & Involvement of learners & 4.20 & 84.00 & Good \\
\hline Source: Primary data processed, (2018) & & &
\end{tabular}

Table 1 above shows the pedagogical content knowledge of prospective economic teachers in accounting education major from 6 aspects. All aspects are in 'good' category. The highest ability is in the involvement of participants with the percentage of 84.00 . This means that the learning activities have been able to invite students to be active and involved in learning. In line with that Shaffat (2009, 61) explains that that learning interaction is a reciprocal communication between teachers and learners with a view to achieving learning objectives, so that communication interaction is a feature of continuity of learning and even can predict the acquisition of learning outcomes. So that the learning is not only teacher centered. Unfortunately, the material mastery aspect which is the main focus of the content knowledge gets the lowest score of 76.25. This means that improvements are needed in the prospective teachers' ability to understand well the economic material in SMA especially those related to basic concepts and demand and supply curves, equilibrium prices, elasticity, the inflation, fiscal and monetary economic policies.

Table 2 The pedagogical content knowledge of teacher candidates in Economics Cooperative major

\begin{tabular}{clccc}
\hline No & Aspect & Mean & Percentage & Remarks \\
\hline 1 & Content Knowledge & 4.38 & 87.50 & Good \\
\hline 2 & Giving aperception and motivation & 4.25 & 85.00 & Good \\
\hline 3 & Strategy & 4.08 & 81.67 & Good \\
\hline 4 & Learning resources/Media & 4.00 & 80.00 & Good \\
\hline 5 & Assessment & 3.83 & 76.67 & Good \\
\hline 6 & Involvement of learners & 3.90 & 78 & Good \\
\hline Source: Primary data processed, (2018)
\end{tabular}

Table 2 above shows the pedagogical content knowledge of teacher candidates in economics cooperatives major from 6 aspects. All aspects are in 'good' category, where the highest ability is in mastery of material with percentage 87.50. This can be interpreted that students in cooperative major are the most skillful ones compared to those in accounting education, business administration and office administrative majors. They chose economic subject that well with the material in high schools. However, the lowest score of 76.67 is on the aspect of assessment which indicates the students ablility to judge both cognitive, affective and psychomotor skills get. The score means that the ability of prospective teachers in conducting assessments in accordance with the curriculum bill applicable in high school still has to be improved. According to Hamzah $(2008,16)$, teachers should be able to carry out effective evaluation and use the results to determine student achievement and progress and can make improvements and development.

Table 3 above shows the pedagogical content knowledge of teacher candidates in economics business major from 6 aspects. Many aspects are in 'enough' category, namely, the mastery of the material, the ability to choose the learning strategy. The ability to use resources and learning media and assessment have to be improved. A newly assessed skill, the ability to engage in apperception and engage students is in 'good' category. However, the core ability to carry out defenders should be improved immediately 
Table 3 The pedagogical content knowledge of teacher candidates in Economics Business major

\begin{tabular}{clccc}
\hline No & Aspect & Mean & Percentage & Remarks \\
\hline 1 & Content Knowledge & 3.74 & 74.79 & Enough \\
\hline 2 & $\begin{array}{l}\text { Giving aperception and } \\
\text { motivation }\end{array}$ & 3.93 & 78.57 & Good \\
\hline 3 & Strategy & 3.72 & 74.44 & Enough \\
\hline 4 & Learning resources/Media & 3.75 & 75.00 & Enough \\
\hline 5 & Assessment & 3.75 & 75.00 & Enough \\
\hline 6 & Involvement of learners & 3.83 & 76.67 & Enough \\
\hline Source: Primary data processed, (2018) & & &
\end{tabular}

Table 4 above shows generally pedagogical content knowledge of economic teacher candidates of office administration from 6 aspects. Many aspects are in 'enough' category, namely, mastering of material, the ability to choose learning strategy, the ability in utilizing source and media of learning assessment and also student involvement still have to be improved. Abilities that are considered 'good' only in apperception and motivation. Apperception and motivation is usually done on the opening activities of learning, but the core learning activities of PCK is still not optimal because PCK is concerned on the manner in which teachers relate their subject matter knowledge (what they know about what they teach) to their pedagogical knowledge (what they know about teaching) and how the subject matter of knowledge is a part of the process of pedagogical reasoning (Mishrah and Koehler, 2006).

Table 4 The pedagogical content knowledge of teacher candidates at Office Administrative major

\begin{tabular}{clccc}
\hline No & Aspect & Mean & Percentage & Remarks \\
\hline 1 & Content Knowledge & 3.73 & 74.64 & Enough \\
\hline 2 & Giving aperception and motivation & 3.93 & 78.57 & Good \\
\hline 3 & Strategy & 3.71 & 74.13 & Enough \\
\hline 4 & Learning resources/Media & 3.73 & 74.57 & Enough \\
\hline 5 & Assessment & 3.76 & 75.24 & Enough \\
\hline 6 & Involvement of learners & 3.79 & 75.71 & Enough \\
\hline Source: Primary data processed, (2018) & & &
\end{tabular}

\section{Conclusions}

1. In general, the pedagogical content knowledge of prospective teachers of accounting education major is considered 'good' but for the material mastery that needs improvement.

2. In general, the pedagogical content knowledge of prospective teachers of cooperative major is 'considered good' but for the assessment aspect that needs improvements.

3. In general, the pedagogical content knowledge of prospective teachers in economics business major is still in 'enough' category. Various aspects need a lot of improvements such as the mastery of the materials, the ability to choose the learning strategy, the ability to use resources and learning media and assessment.

4. In general, the pedagogical content knowledge of prospective teachers in office administrative major is still in 'sufficient' category. As such, a lot of aspects need improvements such as the materials mastery, the ability to choose learning strategies, the ability in utilizing source and media of learning, the assessment and student involvement.

\section{References}

Agustina, Putri. (2015). Pengembangan PCK mahasiswa calon guru FKIP UMS melalui simulasi pembelajaran. Jurnal penelitian dan Pembelajaran IPA.

Arends, Richard. (2008). Learning to Teach. Pustaka Pelajar: Yogyakarta.

Cochran, K. F., \& de Ruiter, J. A. (1993). Pedagogical content knowing: An integrative model for teacher preparation. Journal of teacher Education, 23-272. 
CORD. (2001). Contextual Learning Resource. Retrieved from http://www.cord.org/lev2.cfm/65.

Eded, Tarnedi. (2005). Mengenal Pembelajaran Micro. UNY.

Enfield, M. (2007). Content and pedagogy interaction in the NSTA. Retrieved from http://www. enfield,@msu.edu.

Fauzi, K. M. A. (2008). Pedagogical Content Knowledge (PCK) Melalui Peran Guru dalam Antisipasi Didaktis dan Pedagogis (ADP) Menuju Matematika. Retrieved from http://digilib. unimed.ac.id/.../UNIMED-Article-30983- Pedagogik_UMN.pdf.

Hamzah. (2008). Profesi Kependidikan Problem, Solusi, dan Reformasi Pendidikan di Indonesia. Jakarta: Bumi Aksara.

Hergenhaan, Olson. (2008). Theories of Learning. Jakarta: Kencana Prenada Media.

Loughran, J., Amanda, B., \& Pamela. (2012). Understanding and Developing Science Teacher's Pedagogical Content Knowledge. Second Edition. Netherland: Sense publisher Rotterdam.

Mishra, P., \& Koehler, M. J. (2015). Technological Pedagogical Content Knowledge: A framework for Teacher Knowledge. Teachers College Record, 108(96), 1017-1054.

Mulyasa. (2005). Menjadi Guru Profesional Menciptakan Pembelajaran Kreatif dan Menyenangkan. Bandung: Remaja Rosdakarya.

Shaffat, I. (2009). Optimized Learning Strategy. Jakarta: Prestasi Pustaka.

Sanjaya, Wina. (2007). Strategi Pembelajaran Berorientasi Standar Proses Pendidikan. Jakarta: Kencana.

Schmidt, D. A., et al. (2010). Technological pedagogical content knowledge (TPACK): The development and validation of an assessment instrument for preservice teachers. Journal of Research on Technology in Education, 42(21), 123-149. 